DOI: $10.1515 /$ pts-2017-0010

\title{
ENVIRONMENTAL AND ENERGY ASPECTS OF CONSTRUCTION INDUSTRY AND GREEN BUILDINGS
}

\author{
L.Kauskale $^{1}$, I. Geipele ${ }^{1}$, N. Zeltins ${ }^{2}$, I. Lecis ${ }^{1}$ \\ ${ }^{1}$ Riga Technical University, \\ Institute of Civil Engineering and Real Estate Economics, \\ 6-210 Kalnciema Str., LV-1048, Riga, LATVIA \\ e-mail: Linda.Kauskale@rtu.lv \\ ${ }^{2}$ Institute of Physical Energetics \\ 11 Krivu Str. Riga, LV-1006, LATVIA
}

\begin{abstract}
Green building is an important component of sustainable real estate market development, and one of the reasons is that the construction industry consumes a high amount of resources. Energy consumption of construction industry results in greenhouse gas emissions, so green buildings, energy systems, building technologies and other aspects play an important role in sustainable development of real estate market, construction and environmental development. The aim of the research is to analyse environmental aspects of sustainable real estate market development, focusing on importance of green buildings at the industry level and related energy aspects. Literature review, historical, statistical data analysis and logical access methods have been used in the research. The conducted research resulted in high environmental rationale and importance of environment-friendly buildings, and there are many green building benefits during the building life cycle. Future research direction is environmental information process and its models.
\end{abstract}

Keywords: construction, energy efficiency, environment, sustainable real estate market development.

\section{INTRODUCTION}

The reduction of greenhouse gas emissions is one of the most important environmental priorities globally, and sustainable real estate market development can result in reduction of greenhouse gas emissions as well.

The aim of the research is to analyse environmental aspects of construction and sustainable real estate market development, focusing on importance of green buildings at the industry level and related energy aspects. Literature review, historical, statistical data analysis and logical access methods have been used in the research. Practical part focuses on the case study of Europe and comparison of environmental development tendencies between Germany and Latvia. The object of the 
research is environmental development tendencies. The subject of the research is green building environmental and energy issues. The research comprises experience of the European Union, including case of Latvia and Germany.

Growing attention to environmental protection has changed the corporate practices of construction firms, for example, several studies have shown that some multinational companies have been proactive in environmental management; however, the financial outcomes of environmental practices have not been fully comprehended [1]. The same research suggests that careful distinction needs to be made between the benefits that are planned to be experienced by the company, but for the evaluation of the environmental impacts created by buildings, it is necessary to adopt a life cycle analysis (LCA).

Concepts of sustainability have been described earlier in previous studies [2], [3]. The present research focuses on environmental aspects of real estate market sustainability. The present research is the continuation of previously conducted research on energy aspects in green buildings [4]. An analysis of technical aspects of green buildings has shown a number of opportunities during the building life cycle.

\section{OVERVIEW OF THEORETICAL ASPECTS}

At present, green building construction is considered to be an essential practice for achieving sustainability [5]. As defined in previous studies, "real estate market sustainability is a concept that includes economic, social, environmental, political, technological and legal aspects of real estate market development, long-term national and real estate market development policies that include equity principles, conservation and preservation of the environment and improve the quality of life of society" [3].

Construction industry is one of the largest final consumers of environmental resources and one of the largest emitters of greenhouse gases and other types of pollution, but before the 21 st century, for instance, in China, green building construction has not received much attention [6].

Environmental aspects of real estate market sustainability are of high social and economic importance. Diverging interests and needs with the choice of construction and social goals are:

- Planning effort for financial commitment;

- Energy saving and financial gain;

- Reduction of $\mathrm{CO}_{2}$ and environmental management;

- Use of chemicals and possible pollutants in the production of products [7, p.156].

Green buildings are of special importance in sustainable real estate market development and have environmental, social and economic benefits during the object life cycle for stakeholders and market participants. Building materials also play a significant role in green building costs and energy efficiency aspects.

"A green building material (GBM) is an ecological, health-promoting, recycled, or high-performance building material that impacts the material selection to cover all 
three pillars (3Ps) of sustainability" [8, p.1]. The potential of green building materials based on the three sustainability criteria is shown in Table 1.

Table 1

Potential of GBMs Based on Three Sustainability Criteria [9, p. 3]

\begin{tabular}{|l|l|}
\hline Criteria & Benefit \\
\hline $\begin{array}{l}\text { Environmental } \\
\text { benefits }\end{array}$ & $\begin{array}{l}\text { Enhancing and protecting ecosystems; improving air and water quality; de- } \\
\text { creasing waste streams to air and land; preserving and restoring natural and } \\
\text { renewable resources }\end{array}$ \\
\hline $\begin{array}{l}\text { Economic } \\
\text { benefits }\end{array}$ & $\begin{array}{l}\text { Decreasing operating costs; creating, expanding, and shaping markets for green } \\
\text { products and services; improving occupant productivity; and optimising life- } \\
\text { cycle economic performance }\end{array}$ \\
\hline $\begin{array}{l}\text { Social } \\
\text { benefits }\end{array}$ & $\begin{array}{l}\text { Enhancing occupant comfort and health; heightening aesthetic qualities; mini- } \\
\text { mising strain on local infrastructure; and improving overall quality of life }\end{array}$ \\
\hline
\end{tabular}

Green buildings include a variety of necessary aspects for sustainable development of construction industry, as well as environment and society. Green buildings can be defined as follows:

"Green building is the practice of creating structures and using processes that are environmentally responsible and resource-efficient throughout a building's lifecycle from siting to design, construction, operation, maintenance, renovation and deconstruction. This practice expands and complements the classical building design concerns of economy, utility, durability, and comfort. Green building is also known as a sustainable or high performance building." [10].

"A green building focuses on increasing the efficiency of resource use energy, water, and materials - while reducing building impact on human health and the environment during the building's lifecycle, through better siting, design, construction, operation, maintenance, and removal. Green buildings should be designed and operated to reduce the overall impact of the built environment on its surroundings." [11].

"Green building is a holistic concept that starts with the understanding that the built environment can have profound effects, both positive and negative, on the natural environment, as well as the people who inhabit buildings every day. Green building is an effort to amplify the positive and mitigate the negative of these effects throughout the entire life cycle of a building.". [12].

"Green building is a comprehensive process of design and construction that employs techniques to minimise adverse environmental impacts and reduce the energy consumption of a building, while contributing to the health and productivity of its occupants." [13].

Green building assessment often includes life cycle assessment as well. Methods and concepts of life cycle assessment include the following aspects: cumulative energy expenditure, carbon footprint, virtual water, environmental impact points, MIPS (material intensity per service unit), Eco-Indicator 99, Critical Volumes, ABC Analysis and other methods [14].

Comfort can be influenced by many factors. Indoor comfort factors are shown in Fig. 1. 


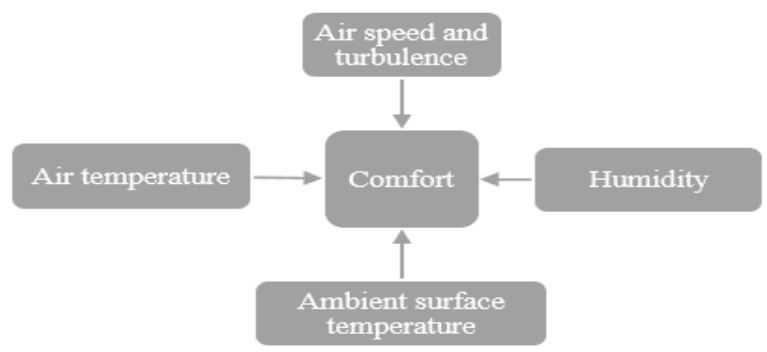

Fig. 1. Comfort factors [7, p.51].

Health aspects are very important in green buildings. According to the research that examined 30 participants in green buildings and conventional buildings for two weeks [6], participants in green buildings experienced significantly lower $\mathrm{CO}_{2}$ concentrations, reports of too little air flow were reduced by $91 \%$, chemical odours by $22 \%$, tobacco smoke odours by $88 \%$, other unpleasant odours by $28 \%$, dryness by $63 \%$, and the participants in green buildings reported half as many symptoms per day as those in the conventional buildings - eye and skin, cognitive, viral, and sensory symptoms were reduced by $67 \%, 70 \%, 28 \%, 50 \%$ and $65 \%$, respectively. As a result, green buildings have lower environmental impacts and improve health and well-being of occupants, by such improvements as ventilation, lighting, materials, and improved indoor environmental quality.

To evaluate design alternatives for economic and environmental criteria, the life cycle assessment methodology can be employed, including the analysis of expanded cumulative exergy consumption that often needs effective systems to recover the negative impacts of waste emissions [15]. Life cycle analysis is crucial for analysis of building impact on environment as well because it includes energy aspects. The general distributive sustainability related to the overall greenhouse gases per capita seems to decrease since 2000; however, the analysis of different gases also indicates some differences in temporal variations and depending on the index used [16]. "Life cycle assessment (LCA) is a system analysis method that is useful in understanding and evaluating the resource consumption and waste emissions associated with products, processes and activities, across all phases of their life cycle from materials acquisition to final disposition" [17]. In the analysis, special attention is devoted to ESG (economic, social and governance) criteria, and in the infrastructure analysis the following criteria are also taken into account [18, p. 5]:

- Diversification at the group level;

- Waste treatment and disposal;

- Water resource management;

- Telecommunications;

- Energy transmission and distribution;

- Energy efficiency;

- Energy generation;

- Transportation;

- Social;

- Other. 
Grey energy and share of primary energy expenditure in the object life cycle should be analysed in the following categories of pre-processes, such as raw material production, production, transport, storage, sales, and post-processes - disposal and demolition / dismantling [7, p. 96]. Energy sources for the calculation of grey energy are shown in Table 2.

Table 2

Energy Sources for the Calculation of Grey Energy [19, p.96]

\begin{tabular}{|l|l|}
\hline Recognised energy carriers & Unrecognised energy carriers \\
\hline $\begin{array}{l}\text { Petroleum, natural gas, coal and all fuel and raw } \\
\text { materials derived from energy value as a result of } \\
\text { combustion }\end{array}$ & $\begin{array}{l}\text { Wood, cork and other vegetable and animal raw } \\
\text { materials, as well as energy carriers derived from } \\
\text { sustainable management }\end{array}$ \\
\hline $\begin{array}{l}\text { Natural uranium with the heat usable in light wa- } \\
\text { ter reactors }\end{array}$ & $\begin{array}{l}\text { Solar energy, geothermal energy, wind energy, } \\
\text { ambient heat and all secondary energy forms }\end{array}$ \\
\hline $\begin{array}{l}\text { Hydroelectric power with the mechanical energy } \\
\text { that can be used on the turbine blade }\end{array}$ & $\begin{array}{l}\text { Plastic waste, waste paper, used tires, sewage } \\
\text { sludge, and other waste recycled materially or } \\
\text { energetically }\end{array}$ \\
\hline
\end{tabular}

Integration of sustainability aspects in the building also gives high technical benefits. Green building environmental benefits are the following [20]:

- Emissions Reduction. Pollutants released by fossil fuel contribute to global climate change, cause air quality issues, such as acid rain and smog, and pose risks to human health [2]. Green building techniques like solar powering, daylighting, and facilitation of public transport increase energy efficiency and reduce harmful emissions.

- Water Conservation. Recycling rainwater and greywater for purposes such as urinal flow and irrigation can preserve potable water and yield significant water savings.

- Stormwater Management. Stormwater runoff can cause waterway erosion, flooding, and carry pollutants into water sources. Harvesting and redirecting storm water, building surfaces with permeable materials, and using green roofs can control and utilise overflow.

- Temperature Moderation. The heat retention properties of tall buildings and urban materials, such as concrete and asphalt, are the primary causes of urban heat island effect. These conditions may be offset by conscientious building design and site selection, as well as planting trees to accompany new developments.

- Waste Reduction. Construction and demolition generates a huge portion of solid waste in the United States. Building deconstruction as an alternative to full-scale demolition results in massive decreases of waste production [15].

Using Germany as an example, just Big Seven locations (Berlin, Dusseldorf, Frankfurt, Hamburg, Cologne, Munich, Stuttgart) have the market share of over $80 \%$, and the unique leader is Munich, where over one billion EUR was invested in certified buildings, followed by Hamburg, Berlin and Frankfurt [21]. The main investors in 2014 were open funds $(47.8 \%$ ), insurance companies $(37.1 \%)$, state funds $(35.3 \%)$, pension funds $(28.4 \%)$ and equity/ real estate funds $(24.1 \%)$ [21]. 
There are many positive environmental aspects of green buildings. At present, investment tendencies are positive in green buildings, and the number of certified green buildings increases.

\section{ENVIRONMENTAL AND ENERGY ASPECTS OF CONSTRUCTION}

Green building activities could help achieve energy efficiency and renewable energy aims. Major greenhouse gases $\left(\mathrm{CO}_{2}, \mathrm{CH}_{4}, \mathrm{~N}_{2} \mathrm{O}\right)$ and two acidic gases $\left(\mathrm{SO}_{\mathrm{x}}\right.$ and $\mathrm{NO}_{\mathrm{x}}$ ) negatively affect the environment [15]. Figure 2 demonstrates carbon dioxide emissions from all NACE activities in Germany and Latvia in period from 2008 to 2012.

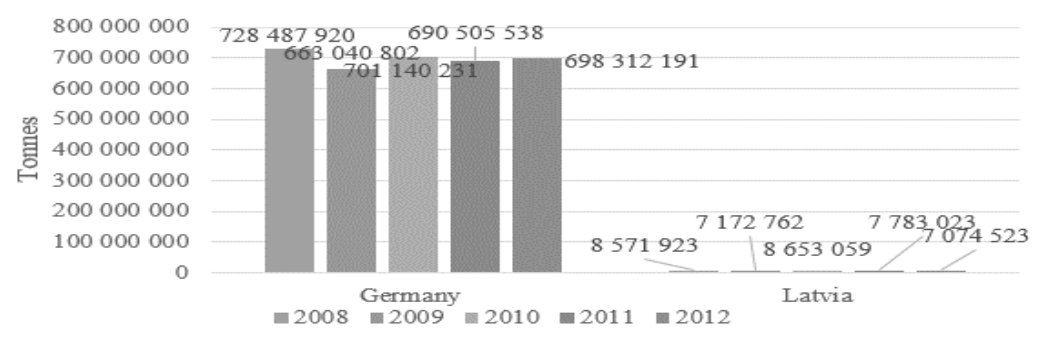

Fig. 2. Carbon dioxide emissions - all NACE activities from 2008 to 2012 [22].

[Figure made by the authors]

Size of market is of high importance in carbon dioxide emissions. Influence of the construction sector on environmental development can show share of carbon dioxide air emissions of construction industry to total emissions (Fig. 3.).

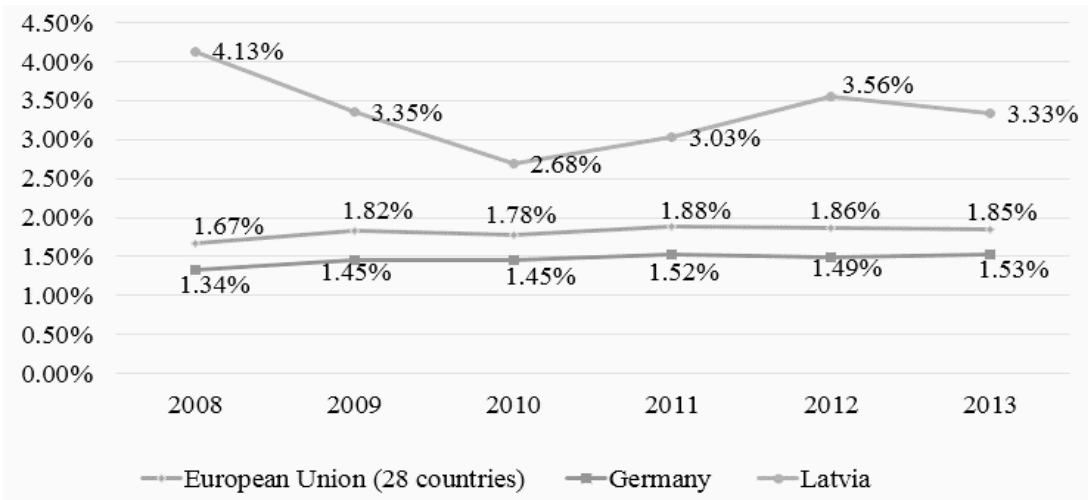

Fig. 3. Share of carbon dioxide air emissions of construction industry to total emissions, $\%$. Data: Eurostat [22]. [Figure made by the authors]

Share of carbon dioxide air emissions of construction industry to total emissions in Latvia is higher than an average EU indicator, which is not a positive tendency. Indicator of Germany is lower than an average indicator in 28 member states of the European Union (EU-28). Data analysis of primary and final energy consumption is also important. Table 3 demonstrates primary and final energy consumption in million tonnes of oil equivalent from 2000 to 2014 in EU, Germany and Latvia. 
Primary and Final Energy Consumption, Million TOE (Tonnes of Oil Equivalent).

Data: Eurostat [22]. Last update 04/02/2016 [Table made by the authors]

\begin{tabular}{|c|c|c|c|c|c|c|c|c|}
\hline $\begin{array}{l}\text { GEO/ } \\
\text { TIME }\end{array}$ & \multirow{16}{*}{ 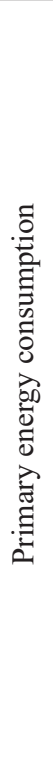 } & EU-28 & Germany & Latvia & \multirow{16}{*}{ 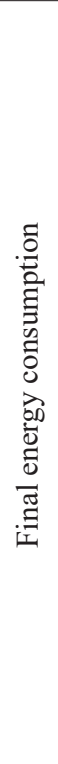 } & EU-28 & Germany & Latvia \\
\hline 2000 & & 1617.9 & 317.3 & 3.8 & & 1132.8 & 220.0 & 3.3 \\
\hline 2001 & & 1658.2 & 327.3 & 4.1 & & 1156.5 & 223.6 & 3.6 \\
\hline 2002 & & 1653.4 & 319.7 & 4.0 & & 1144.6 & 220.1 & 3.6 \\
\hline 2003 & & 1690.5 & 318.3 & 4.3 & & 1176.3 & 223.5 & 3.8 \\
\hline 2004 & & 1708.5 & 320.1 & 4.4 & & 1188.9 & 221.6 & 3.9 \\
\hline 2005 & & 1712.8 & 317.2 & 4.5 & & 1191.8 & 218.5 & 4.0 \\
\hline 2006 & & 1722.0 & 327.6 & 4.7 & & 1193.0 & 223.4 & 4.2 \\
\hline 2007 & & 1693.6 & 310.4 & 4.8 & & 1172.9 & 210.2 & 4.4 \\
\hline 2008 & & 1693.1 & 315.2 & 4.6 & & 1180.0 & 217.6 & 4.2 \\
\hline 2009 & & 1599.4 & 296.0 & 4.4 & & 1114.7 & 205.8 & 4.0 \\
\hline 2010 & & 1656.4 & 310.4 & 4.6 & & 1163.3 & 219.7 & 4.1 \\
\hline 2011 & & 1593.3 & 294.4 & 4.3 & & 1105.0 & 208.8 & 3.9 \\
\hline 2012 & & 1584.0 & 296.8 & 4.4 & & 1104.5 & 212.1 & 4.0 \\
\hline 2013 & & 1569.1 & 302.8 & 4.4 & & 1106.2 & 217.7 & 3.9 \\
\hline 2014 & & 1507.1 & 291.8 & 4.4 & & 1061.2 & 208.9 & 3.9 \\
\hline
\end{tabular}

In Latvia, primary and final energy consumption is increasing, but in Germany and the European Union in general - the decreasing tendencies are observed. Economic aspect of the used energy results in energy prices. Tables 4 and 5 show energy price tendencies for gas and electricity for domestic and industrial consumers in Germany and Latvia in 2016S1.

Table 4

Gas Prices for Consumers - Bi-annual Data, All Taxes and Levies Included, in 2016S1, Unit Kilowatt-Hour, in Euro [22]. [Table made by the authors]

\begin{tabular}{|c|c|c|}
\hline GEO/TIME & Germany & Latvia \\
\hline \multicolumn{3}{|l|}{ Gas prices for domestic consumers } \\
\hline Band D1 : Consumption $<20$ GJ & 0.1091 & 0.0698 \\
\hline Band D2 : 20 GJ $<$ Consumption $<200$ GJ & 0.0661 & 0.0424 \\
\hline Band D3 : Consumption > $200 \mathrm{GJ}$ & 0.0610 & 0.0424 \\
\hline \multicolumn{3}{|l|}{ Gas prices for industrial consumers } \\
\hline Band I1 : Consumption $<1000 \mathrm{GJ}$ & 0.0539 & 0.0406 \\
\hline Band I2 : $1000 \mathrm{GJ}<$ Consumption $<10000 \mathrm{GJ}$ & 0.0423 & 0.0364 \\
\hline Band I3 : 10000 GJ $<$ Consumption $<100000$ GJ & 0.0404 & 0.0323 \\
\hline Band I4 : 100000 GJ $<$ Consumption $<1000000$ GJ & 0.0316 & 0.0301 \\
\hline Band I5 : $1000000 \mathrm{GJ}<$ Consumption $<4000000$ GJ & 0.0264 & 0.0291 \\
\hline Band I6 : Consumption > 4000000 GJ & 0.0246 & : \\
\hline
\end{tabular}


Electricity Prices for Domestic and Industrial Consumers, Bi-annual Data, all Taxes and Levies Included, Unit Kilowatt-Hour, in Euro [22]. [Table made by the authors]

\begin{tabular}{|c|c|c|}
\hline GEO/TIME & Germany & Latvia \\
\hline \multicolumn{3}{|l|}{ Electricity prices for domestic consumers } \\
\hline Band DA : Consumption $<1000 \mathrm{kWh}$ & 0.4555 & 0.1614 \\
\hline Band DB : $1000 \mathrm{kWh}<$ Consumption $<2500 \mathrm{kWh}$ & 0.3263 & 0.1630 \\
\hline Band DC : $2500 \mathrm{kWh}<$ Consumption $<5000 \mathrm{kWh}$ & 0.2969 & 0.1628 \\
\hline Band DD : $5000 \mathrm{kWh}<$ Consumption $<15000 \mathrm{kWh}$ & 0.2812 & 0.1619 \\
\hline Band DE : Consumption $>15000 \mathrm{kWh}$ & 0.2680 & 0.1583 \\
\hline \multicolumn{3}{|l|}{ Electricity prices for industrial consumers } \\
\hline Band IA : Consumption $<20 \mathrm{MWh}$ & 0.2804 & 0.1852 \\
\hline Band IB : $20 \mathrm{MWh}<$ Consumption $<500 \mathrm{MWh}$ & 0.2259 & 0.1555 \\
\hline Band IC : $500 \mathrm{MWh}<$ Consumption $<2000 \mathrm{MWh}$ & 0.1974 & 0.1410 \\
\hline Band ID : $2000 \mathrm{MWh}<$ Consumption $<20000 \mathrm{MWh}$ & 0.1712 & 0.1300 \\
\hline Band IE : $20000 \mathrm{MWh}<$ Consumption $<70000 \mathrm{MWh}$ & 0.1398 & 0.1211 \\
\hline Band IF : $70000 \mathrm{MWh}<$ Consumption $<150000 \mathrm{MWh}$ & 0.1130 & 0.0946 \\
\hline Band IG : Consumption $>150000 \mathrm{MWh}$ & - & - \\
\hline
\end{tabular}

Energy prices differ by consumer groups; however, energy prices for all groups are important for the development of all sectors of national economy. Example of the construction industry shows that sustainable development of construction industry plays an important role in the balanced environmental development.

\section{RESULTS AND DISCUSSION}

The research results have shown that there is a need for green building construction, but at the same time there are a number of risks and conflicting criteria during its implementation. As sustainable development includes also social and economic factors, an optimal balance should be found by market participants. Investment tendencies to green buildings are also of special importance, as financial aspects and information are one of the important factors for construction of green buildings.

\section{CONCLUSIONS}

1. The construction industry exerts a great influence on environmental development, and green buildings include a variety of positive aspects and parameters for sustainable development of construction industry.

2. Consumption of energy is of high environmental importance, and at the same time energy prices play an important socio-economic role. Energy consumption volumes are the criteria that affect energy prices, and each country has a particular structure of companies by size and other criteria. Energy efficiency policies should differ among different sectors of real estate (and its subsectors) by type of activities, different groups of society, etc.

3. Share of carbon dioxide emissions in Latvia is much lower in comparison with Germany due to the size of market, but share of carbon dioxide emissions in the construction industry, in particular, is higher. The research results show that according to the analysed indicators, energy development tendencies in Germany 
and Latvia differ. Implementation of effective energy policies in the construction industry can give positive results for environmental development in the long term for many market participants, i.e., they can influence the business sector - construction entrepreneurs and renters, households (consumers of energy during the building life cycle) and government buildings in the construction and maintenance period.

\section{REFERENCES}

1. Chen, P.-H., Ong, C.-F., \& Hsu, S.-C. (2016). Understanding the relationships between environmental management practices and financial performances of multinational construction firms. Journal of Cleaner Production, 139, 750-760. http://dx.doi. org/10.1016/j.jclepro.2016.08.109

2. Kauškale, L., \& Geipele, I. (2016). Economic and social sustainability of real estate market and problems of economic development - a historical overview. Baltic Journal of Real Estate Economics and Construction Management, 4(1), 2255-9671. DOI: 10.1515/ bjreecm-2016-0002

3. Kauškale, L., \& Geipele, I. (2017). Integrated approach of real estate market analysis in sustainable development context for decision making. Procedia Engineering, 172, 505512. DOI:10.1016/j.proeng.2017.02.059

4. Kauškale, L., Geipele, I., Zeltiņš, N., \& Lecis, I. (2016). Energy aspects of green buildings - international experience. Latvian Journal of Physics and Technical Sciences, 6, 21-28. DOI:10.1515/lpts-2016-0040

5. Vyas, G.S., \& Jha, K.N. (2017). Benchmarking green building attributes to achieve cost effectiveness using a data envelopment analysis. Sustainable Cities and Society. 28, $127-$ 134.http://dx.doi.org/10.1016/j.scs.2016.08.028

6. MacNaughton, P., Spengler, J., Vallarino, J., Santanam, S., Satish, U., \& Allen, J. (2016). Environmental perceptions and health before and after relocation to a green building. Building and Environment, 104, 138-144. http://dx.doi.org/10.1016/j.buildenv.2016.05.011

7. Neddermann, R., \& Weber, C. (2016). Energetische Optimierung im Wochnungsbau. Wirtschaftlichkeit - Nutzen - Effizienz [Energetic Optimization in Construction. Profitability - Usage - Efficiency]. Stuttgart: Fraunhofer IRB.

8. Khoshnava, S.M., Rostami, R., Valipour, A., Ismail, M., \& Rahmat, A.R. (2016). Rank of green building material criteria based on the three pillars of sustainability using the hybrid multi criteria decision making method. Journal of Cleaner Production, 1-18. DOI: $10.1016 /$ j.jclepro.2016.10.066

9. U.S. Environmental Protection Agency. (2009). Municipal Solid Waste Generation, Recycling, and Disposal in the United States: Facts and Figures for 2008. EPA530-F-009-021. Washington, D.C. Retrieved 11 November 2016 from www.epa.gov/ epawaste/nonhaz/ municipal/pubs/msw2008rpt.pdf

10. US Environmental protection agency. Green Building. Retrieved 20 November 2016 from https://archive.epa.gov/greenbuilding/web/html/

11. Greenbuildingindex SDN BHD. What is Green Building? Retrieved 20 November 2016 from http://new.greenbuildingindex.org/whatandwhy

12. U.S. Green Building Council. What is green building? Retrieved 20 November 2016 from http://www.usgbc.org/articles/what-green-building

13. Smith College. Smith Sustainability News. Glossary of Green Terms. Retrieved 11 November 2016 from https://www.smith.edu/green/news_glossary.php

14. Springer Gabler Publishing House. Gabler Wirtschaftslexikon [Gabler Economic Lexicon]. Ökobilanz [Life Cycle Assessment]. Retrieved 11 November 2016 from http:// wirtschaftslexikon.gabler.de/Archiv/57090/oekobilanz-v13.html] 
15. Wang, W., Zmeureanu, R., \& Rivard, H. (2005). Applying multi-objective genetic algorithms in green building design optimization. Building and Environment, 40, 1512-1525. DOI:10.1016/j.buildenv.2004.11.017

16. Duro, J.A. (2016). Intercountry inequality on greenhouse gas emissions and world levels: An integrated analysis through general distributive sustainability indexes. Ecological Indicators, 66, 173-179. http://dx.doi.org/10.1016/j.ecolind.2016.01.026

17. Barnthouse, L., Fava, J., Humphreys, K., Hunt, R., Laibson, L., Noesen, S., Norris, G., Owens, J., Todd, J., Vigon, B., Weitz, K., \& Young, J. (2005). Life Cycle Impact Assessment: The State-of-the-Art (2nd ed). Pensacola, FL: SETAC Press 1998, as cited in W. Wang, R. Zmeureanu, \& H. Rivard (2005). Applying multi-objective genetic algorithms in green building design optimization. Building and Environment, 40, 1512-1525. DOI:10.1016/j.buildenv.2004.11.017

18. GRESB B.V. Infrastructure. 2016 Report. Retrieved 20 November 2016 from https:// gresb-public.s3.amazonaws.com/2016/content/2016_Infrastructure_Report.pdf

19. WECOBIS Bundesministerium für Umwelt, Naturschutz, Bau und Reaktorsicherheit [Federal Ministry for the Environment, Nature Conservation, Construction and Nuclear Safety, German Federation] and Bayerischen Architektenkammer (ByAK) [Bavarian Chamber of Architects (ByAK)]. (2016). Energy Sources for the Calculation of Grey Energy as cited in T. Duzia, \& R. Mucha (2016). Energetisch optimiertes Bauen: technische Vereinfachung - nachhaltige Materialien - wirtschaftliche Bauweisen [Energetically optimized construction: technical simplification - sustainable materials - economical construction]. Stuttgart: Fraunhofer.

20. National Association of Home Builders. (1998). Deconstruction: Building Disassembly and Material Salvage, as cited in The City of Bloomington. Green Building benefits. Retrieved 10 November 2016 from https://bloomington.in.gov/green-building-benefits

21. BNP Paribas Real Estate. (2014). Market Focus. Investmentmarkt green Buildings 2014 [Market Focus. Investment market of green buildings]. Retrieved 20 January 2017 from https:/www.realestate.bnpparibas.de/upload/docs/application/pdf/2016-05/2014-q4_ green_building_investment_de_final.pdf?id=p_1626804\&hreflang=de

22. European Statistics Database Eurostat. Statistics Database. Retrieved 20 November 2016 from http://ec.europa.eu/eurostat/data/database

\title{
BŪVNIECİBAS NOZARES VIDES UN ENERGḠTIKAS ASPEKTI, UN ZAL̀Ā BŪVNIECİBA
}

\author{
L.Kauškale, I.Geipele, N.Zeltiņš, I.Lecis
}

\section{Kopsavilkums}

Zạ̣ā būvniecība ir svarīga ilgtspējīgas būvniecības nozares un nekustamā īpašuma tirgus attīstības dala, kas saistîta ar būvniecības nozarei raksturīgo lielo resursu patēriṇu. Būvniecības nozares darbības rezultātā enerǵijas patēriņš rada siltumnīcefekta gāzu emisijas, tāpēc zaḷai būvniecībai, enerğijas sistēmām, ilgtspējīgām būvniecības tehnologijāàm, energoresursu cenām un citiem svarīgiem jautājumiem ir būtiska nozīme ilgtspējīgā būvniecības nozares un nekustamā īpašuma tirgus attīstībā, un kopējai vides attīstībai valstī. Veiktā pētījuma rezultāti atspogulo augsto videi draudzīgas būvniecības ekologisko nozīmi. Pētījuma gaitā tiek analizētas dažādas zaļo ēku būvniecības priekšrocības ēku un būvju dzīves cikla laikā, un enerǵijas resursu cenas.

$$
\text { 06.02.2017. }
$$

